\title{
Variation in the chemical quality of woody supplements for nursery growing media affects growth of tree seedlings
}

\author{
Bartosz Adamczyk ${ }^{1}$ D . Sylwia Adamczyk ${ }^{1}$. Veikko Kitunen ${ }^{1} \cdot$ Tuija Hytönen $^{1}$. \\ Raisa Mäkipää ${ }^{1} \cdot$ Taina Pennanen ${ }^{1}$
}

Received: 14 December 2020 / Accepted: 20 October 2021 / Published online: 5 November 2021

(c) The Author(s) 2021

\begin{abstract}
Tree seedlings are produced in tree nurseries. However, nursery-grown seedlings often exhibit poor performance after outplanting due to the lack of adaptation to harsh natural conditions. These nursery-grown seedlings do not necessarily possess well-developed ectomycorrhizal symbionts, which help to obtain nutrients and increase resilience in exchange for seedling photoassimilated carbon. To improve the quality of the seedlings in natural conditions, we sowed spruce seeds on growing media with the addition of wood chips, i.e. stemwood chips or polyphenol- and resin acid-rich knotwood chips. Wood chips were chosen because they are common forest side-streams, and their compounds have shown a potential to improve mycorrhization and seedling fitness. Wood chips initially decreased the growth of seedlings. However, this effect levelled off with time and depended on the quality of the wood. Wood chips had no effect on mycorrhization. Further testing of the wood material showed that wood chips seemed to decrease seedling growth via nitrogen (N) immobilisation rather than a direct toxic effect. The phenomenon of $\mathrm{N}$ immobilisation on wood chips could be explored further to develop a slow-release $\mathrm{N}$ source, aptly reflecting $\mathrm{N}$ availability in natural conditions. Slow-release $\mathrm{N}$ source based on wood chips could be beneficial both to increase survival in natural conditions and for environment protection.
\end{abstract}

Keywords Forest nursery $\cdot$ Growing media $\cdot$ Nitrogen uptake $\cdot$ Tree seedlings $\cdot$ Wood chemistry

\section{Introduction}

Norway spruce (Picea abies (L.) Karst) is one of the most economically and ecologically important tree species in Central and Northern Europe (Johnson and More 2004). Spruce wood is commonly used for timber constructions and pulpwood for paper and furniture. Due to high demand for its wood and relatively high productivity, as well as tolerance to various soil conditions and herbivores, spruce is widely used in forest stand regeneration (Savill 2013). Compared to bare-rooted seedlings the planting of

Bartosz Adamczyk

bartosz.adamczyk@luke.fi

1 Natural Resources Institute Finland (Luke), PL 2, Latokartanonkaari 9, 00790 Helsinki, Finland 
containerised Norway spruce seedlings has been shown to be a more reliable regeneration method (Grossnickle 2000; Miina and Saksa 2013). Forest tree seedling production in Finland, as in the whole of Fennoscandia, therefore relies on a containerised production system (OSF: Natural Resources Institute Finland https://statdb.luke.fi/) with the use of peat products as growing media.

The prevalent nursery growing methods include fertilisation with soluble mineral nutrients, which reduces the relative size of seedling roots and decreases ectomycorrhizal fungi (EMF) colonisation and diversity (McAlister and Timmer 1998; Flykt et al. 2008). Ectomycorrhizal fungi are crucial for tree water and nutrient uptake. EMF deficiency in nursery growing seedlings therefore impedes tree fitness and increases vulnerability to pathogens after outplanting (Quoreshi and Timmer 2000; Klavina et al. 2016). In addition, Norway spruce seedlings after outplanting suffer from herbivorous damage (Huitu et al. 2009). The reason is that herbivores (voles, ungulates, insects) prefer planted nursery seedlings due to their high nitrogen $(\mathrm{N})$ content and low content of defensive compounds, i.e. phenolics and alkaloids (Burney and Jacobs 2013; Virjamo et al. 2013; Karst et al. 2015; Muiruri et al. 2019). As environmental reasons impede the use of peat (Boldrin et al. 2010), there is an urgent need to search for peatless growing media that provide better chances of survival after outplanting.

Wood fractions and other forest side-streams have already shown some potential to enhance the growth rate of Norway spruce seedlings via an improvement in mycorrhization and root/shoot ratio (Vaario et al. 2009). In forest stands, the occurrence of natural seedlings is positively correlated with decaying wood substrate (Alaspää et al. 2016). Decaying wood logs are known to host diverse fungal communities including mycorrhizal species, especially in later decay phases (Rajala et al. 2010, 2012, 2015; Rinne-Garmston et al. 2019). Since wood N concentration increases with decay phase due to asymbiotic nitrogen fixation and transfer of $\mathrm{N}$ from the soil (Rinne et al. 2017), advanced decay phase wood is probably a better $\mathrm{N}$ source for seedlings than fresh wood substrate. Moreover, wood compounds may increase seedling resilience via the activation of plant's defence metabolism (Mandal et al. 2010). For example, lignans (a group of polyphenolics) exert strong antioxidant activity (Harmatha and Dinan 2003; Korkina 2007; Balík et al. 2017). Lignans are thus potentially very effective inducers of plant defence. Lignans reside almost exclusively in knots, not in the stemwood (Willför et al. 2004, 2005; Piispanen et al. 2008; Wijayanto et al. 2015). Knotwood is a typical forestry side-stream that is abundantly accessible from forest cutting residuals. In addition, knotwood contains a high amount of terpenes, which also act as defensive compounds (Manninen et al. 2002; Adamczyk et al. 2011, 2013).

However, these wood compounds do not leave other non-defence-related metabolic and soil processes untouched. For example, polyphenolics and terpenes may affect enzymatic activities in soil and bind organic N compounds (Joanisse et al. 2007; Hagerman 2012; Adamczyk et al. 2015, 2017), potentially affecting seedling growth and fitness. Altogether, the improvement of nursery-grown seedling performance and opportunities for competitive success seem to rely on a build-up of a root system that can provide sufficient nutrients and water, and the development of an effective defence against pathogens and herbivores, both of which involve beneficial symbioses with mycorrhizal fungi (Read 1996; Grossnickle 2000; Karst et al. 2015).

Here we examined the effects of two chemically varying wood materials, standard stemwood chips and knotwood chips, on the early performance of nursery tree seedlings. We aimed to obtain a holistic understanding of the effects of woody substrate addition to 
nursery growing media on plant growth, $\mathrm{N}$ uptake, and symbiotic associations in roots. To achieve this goal we conducted the following series of experiments:

(a) First aim was to observe the effect of wood chemistry on Norway spruce seedling growth and the potential to form mycorrhizal symbiosis. We therefore established nursery experiments in which the seedlings grew on substrate with the addition of standard stemwood chips (SW), knotwood chips (KW), or stemwood in various stages of decomposition.

(b) Second, we aimed to decipher the mechanisms behind seedling growth reduction after the addition of knotwood observed in the first experiment. We hypothesised that the reduction in growth was due to the immobilisation of $\mathrm{N}$ on the wood chips. We thereby established a second nursery experiment in which we grew the seedlings with wood chips soaked in a nutrient solution, as well as with wood chips with immobilised ${ }^{15} \mathrm{~N}$. Here we traced the effect of wood chips on $\mathrm{N}$ availability for spruce seedlings. We also performed a laboratory experiment that aimed to estimate $\mathrm{N}$ immobilisation potential on wood chips.

(c) Third, we assessed spruce seed germination rates and the effect of lignan extract purified from knotwood on the seeds to rule out the toxicity of lignan-rich knotwood chips.

\section{Materials and methods}

Nursery experiment 1 Effect of knot- and stemwood chips on seedling performance.

In the first nursery experiment, spruce seeds (seed orchard R01-89-1001 Sv 110) were sown in Plantek-81F containers (volume $85 \mathrm{~cm}^{3}$, BCC $\mathrm{Ab}$ ) supplemented with mixtures of wood chips, peat, and vermiculite (2-4 mm, SP-Minerals, Finland). The conventional growing media (control) was a mixture of Sphagnum peat (90\% in volume, $\mathrm{pH} 4.3$, NPK $16-4-17 \mathrm{~kg} / \mathrm{m}^{3}$, Kekkilä-BVB Oy), and $10 \%(\mathrm{v} / \mathrm{v})$ of vermiculite. The treatments were obtained by replacing part of the conventional growing media with woody material as follows: $10 \%$ (volume) and $30 \%$ of knotwood chips (KW) or stemwood chips (SW). Wood chips were obtained from freshly cut wood logs of Norway spruce harvested from southern Finland (Ruotsinkylä, 60.369090, 24.972714). The chips were stored in a $+4{ }^{\circ} \mathrm{C}$ cold room before use. Spruce knotwood contains five times more extractives than SW. Moreover, KW contains far more lignans and resin acids than SW (Nisula 2018).

Nursery experiment 1 was arranged in a randomized design. Altogether, 486 seeds (two PL81 containers per treatment, which makes $2 \times 81$ seedlings per treatment) were sown in May 2016. Seedlings were grown outdoors at the Luke Haapastensyrjä experimental nursery in southern Finland (60 $36^{\prime} 59.6^{\prime \prime} \mathrm{N} 24^{\circ} 25^{\prime} 52.3^{\prime \prime}$ E) for three growing seasons and fertilised with Superex fertilisers (Kekkilä-BVB Oy, NPK 12-5-27) to keep the conductivity around $1 \mathrm{mS} \mathrm{m} \mathrm{m}^{-1}$.

Nursery experiment 2 Effect of nutrient-soaked knotwood and stemwood on seedling performance and EMF colonisation.

In the second nursery experiment established in 2017, spruce seeds (seed orchard R01-89-1001 Sv 110) were sown in Plantek-81F containers (volume $85 \mathrm{~cm}^{3}$, BCC $\mathrm{Ab}$ ) supplemented with mixtures of wood chips, Sphagnum peat, and vermiculite, as in nursery experiment 1 . The conventional growing media (control) was similar to that in nursery experiment 1 . The treatments were obtained by replacing part of the conventional growing media with woody material, as presented in Table 1. Lignan 1 
Table 1 Treatments in the Nursery experiment 2

\begin{tabular}{|c|c|c|c|c|}
\hline Treatment & Abbreviation & Wood material & Nutrient addition & Fungal inocula \\
\hline $5 \%$ knotwood $+\mathrm{N}$ & $5 \% \mathrm{KWN}$ & $5 \%$ knotwood & Soaked & - \\
\hline $5 \%$ stemwood $+\mathrm{N}$ & $5 \% \mathrm{SWN}$ & $5 \%$ stemwood & Soaked & - \\
\hline $10 \%$ knotwood $+\mathrm{N}$ & $10 \% \mathrm{KWN}$ & $10 \%$ knotwood & Soaked & - \\
\hline $10 \%$ stemwood $+\mathrm{N}$ & $10 \%$ SWN & $10 \%$ stemwood & Soaked & - \\
\hline $10 \%$ knotwood & $10 \% \mathrm{KW}$ & $10 \%$ knotwood & - & - \\
\hline $10 \%$ stemwood & $10 \% \mathrm{SW}$ & $10 \%$ stemwood & - & - \\
\hline $\begin{array}{l}10 \% \text { knot- } \\
\text { wood }+\mathrm{N}+\mathrm{EMF}\end{array}$ & $10 \% \mathrm{KWN}+\mathrm{EMF}$ & $10 \%$ knotwoot & Soaked & Mycelia inoculum \\
\hline $\begin{array}{l}10 \% \text { stem- } \\
\quad \text { wood }+\mathrm{N}+\mathrm{EMF}\end{array}$ & $10 \% \mathrm{SWN}+\mathrm{EMF}$ & $10 \%$ stemwood & Soaked & Mycelia inoculum \\
\hline Lignan extract 1 & LIGNAN1 & $300 \mathrm{~mL}$ lignan 1 & - & - \\
\hline Lignan extract 2 & LIGNAN2 & $100 \mathrm{~mL}$ lignan 2 & - & - \\
\hline $5 \%$ decaywood 1 & $5 \%$ DECAY 1 & $5 \%$ decay 1 wood & - & Decay wood \\
\hline $10 \%$ decaywood 1 & $10 \%$ DECAY 1 & $10 \%$ decay 1 wood & - & Decay wood \\
\hline $5 \%$ decaywood 4 & $5 \%$ DECAY4 & $5 \%$ decay 4 wood & - & Decay wood \\
\hline $10 \%$ decaywood 4 & $10 \%$ DECAY4 & $10 \%$ decay 4 wood & - & Decay wood \\
\hline $10 \%$ decaywood & $10 \%$ DECAY & $10 \%$ decay $3-5$ wood & - & Dry decay wood \\
\hline Conventional peat & CONVENTIONAL & - & - & - \\
\hline
\end{tabular}

treatment was obtained by mixing $300 \mathrm{~mL}$ of lignan extract $1(130 \mathrm{mg} / \mathrm{L})$ and $100 \mathrm{~mL}$ of Lignan $2(360 \mathrm{mg} / \mathrm{L})$ to $4 \mathrm{~L}$ of growing media. Lignans were extracted and purified from fresh spruce inner branches (dried and ground to ca. $2 \mathrm{~mm}$ chips with Fritsch Pulverisette mill, Fritsch GmbH, model 15,903, Idar-Oberstein, Germany) with water in a 3-L flowthrough extractor (Konepaja Viitosmetalli, Paaso) at $100-120{ }^{\circ} \mathrm{C}$. Extraction $100-120{ }^{\circ} \mathrm{C}$ yielded a pure sample, which did not contain measurable amounts of resin acids (confirmed with gas chromatography-mass spectrometry) and was soluble in water. During flowthrough extraction, the majority of lignans is eluted in small volumes and thus at high concentration. The other lignans were recovered by concentrating the clear extraction solution.

Decay wood substrate that represented decay phases 1 and 4 was obtained from an unmanaged Norway spruce stand in southern Finland (Lapinjärvi 60 $39^{\prime} 09$ N 26 $07^{\prime}$ $04 \mathrm{E}$ ), and was sampled for an earlier study (Rinne-Garmston et al. 2019). Decay phase 1 represented trees felled only a few years ago with wood still hard and bark intact, whereas in decay phase 4, the wood was very decayed and soft with no hard core (Mäkipää et al. 2018). The decay phases were classified as in Mäkinen et al. (2006). In addition, decay wood substrate that was dried at $100{ }^{\circ} \mathrm{C}$ and had therefore lost the majority of fungal activity was used for comparison. For nursery experiment 2, 36 seeds per treatment were sown in containers in May, and the seedlings were grown outdoors at the Luke Haapastensyrjä experimental nursery for three growing seasons. Some of the seedlings were inoculated with ectomycorrhizal fungi: R-SP02 Piloderma olivaceum, R-SP01-HK3 Tylospora asterophora, and R-FC03 Cenococcum geophilum. The ECM fungal strains are deposited in the microbial culture collection of Natural Resources Institute Finland, Helsinki. Fungi were isolated from the ECM root tips of young Norway spruce seedlings growing in natural habitats (Vuorinen et al. 2015). Inoculum was obtained by growing mycelia plugs in $1 / 2 \mathrm{MMN}$ nutrient media (100 rpm shaking) for two months. Five $\mathrm{mL}$ of inocula per seedling was 
pipetted to the roots of seedlings in June. All the seedlings were fertilised with Superex fertilisers (Kekkilä-BVB Oy, Finland NPK 12-5-27) to keep the conductivity around 1 $\mathrm{mS} \mathrm{m}^{-1}$.

Nursery experiment 2 was arranged in a randomized design. Altogether, we used 36 seedlings per treatment. Seedlings were grown outdoors at the Luke Haapastensyrjä experimental nursery in southern Finland (60 36 $\left.59.6^{\prime \prime} \mathrm{N} 24^{\circ} 25^{\prime} 52.3^{\prime \prime} \mathrm{E}\right)$.

Laboratory experiment Immobilisation of $\mathrm{N}$ on wood chips.

We compared the ability of stemwood vs knotwood to immobilise ammonium and nitrate ions. Wood chips $(10,25,50 \mathrm{mg})$ were weighed into Eppendorf tubes. Then, $250 \mu \mathrm{L}$ of water was added, and after $10 \mathrm{~min}, 1 \mathrm{~mL}$ of $5 \mathrm{mM} \mathrm{NH}_{4} \mathrm{Cl}$ or $\mathrm{KNO}_{3}(9.5 \mathrm{mM}$, equal amount of $\mathrm{N}$ to $5 \mathrm{mM} \mathrm{NH}_{4} \mathrm{Cl}$ ) was added and mixed for 30 min on a planar shaker (200 rpm). No wood chips were used as a first blank. As a second blank, $1 \mathrm{~mL}$ of water instead of $\mathrm{NH}_{4} \mathrm{Cl}$ or $\mathrm{KNO}_{3}$ was used. After centrifugation (5 min, 12,000 g), the residual amount of $\mathrm{NH}_{4} \mathrm{Cl}$ or $\mathrm{KNO}_{3}$ was measured from supernatant using spectrophotometric methods (Adamczyk et al. 2019).

In the following laboratory experiment, we estimated the stability of $\mathrm{N}$-bound to knotwood and stemwood chips. Wood chips $(50 \mathrm{mg})$ with bound ammonium-N were prepared as above. The precipitates were washed with $1 \mathrm{~mL}$ of water, mixed for $5 \mathrm{~min}$, and after centrifugation ( $5 \mathrm{~min}, 5000 \mathrm{~g}$ ), supernatants were used to study the residual amount of ammonium as above. Later, the washing was repeated. We added $1 \mathrm{~mL}$ of $1 \mathrm{M} \mathrm{KCl}$ (a common extractant used in soil studies) to the wood chips, mixed it for $30 \mathrm{~min}$ in a planar shaker (200 rpm), and after centrifugation $(5000 \mathrm{~g}, 5 \mathrm{~min})$, we measured the residual amount of ammonium using the spectrophotometric method (Adamczyk et al. 2019).

Lab experiment was arranged in a randomized design with four replicates per each treatment.

Nursery experiment 3 Uptake of ${ }^{15} \mathrm{~N}$ immobilised on wood chips by nursery seedlings.

The third nursery experiment was conducted in 2017 with 1-year-old spruce seedlings from nursery experiment 1 (control treatment), to which small mesh bags $(1 \times 1 \mathrm{~cm}, 50 \mu \mathrm{m}$ mesh size) containing $50 \mathrm{mg}$ of wood chips with $5 \mathrm{mg}$ of ${ }^{15} \mathrm{~N}$-ammonium bound to it were added. These mesh bags allow fungal but not root ingrowth. In this experiment, we compared the seedling uptake of ${ }^{15} \mathrm{~N}$ bound to knotwood vs stemwood chips. Wood chips with immobilised ${ }^{15} \mathrm{~N}$-ammonium were prepared as above for the laboratory experiment and washed with water to remove unbound-N. We used $1.25 \mathrm{mM} \mathrm{NH}_{4} \mathrm{Cl}$ for knotwood chips $(\mathrm{KW})$ and $5 \mathrm{mM} \mathrm{NH} \mathrm{N}_{4} \mathrm{Cl}$ for stemwood chips (SW) to obtain an equal amount of bound-N for both wood chip types. The amount of bound-N to wood chips was measured as above. Later, wet wood chips with immobilised ${ }^{15} \mathrm{~N}$ were placed in the mesh bags and transferred to the growing media of spruce seedlings. We used the following treatments: (1) mesh bags filled with KW with immobilised ${ }^{15} \mathrm{~N}$; (2) mesh bags filled with $\mathrm{KW}$ with immobilised ${ }^{14} \mathrm{~N}$; (3) mesh bags filled with SW with immobilised ${ }^{15} \mathrm{~N}$; and (4) mesh bags filled with $\mathrm{SW}$ with immobilised ${ }^{14} \mathrm{~N}$. The amount of $\mathrm{N}$ in every treatment was equal.

Nursery experiment 3 was arranged in a randomized design with ten replicate mesh bags per treatment. Mesh bags were buried in the rhizosphere of 1-year-old nursery seedlings (seed orchard R01-89-1001 Sv 110) with one bag per seedling, and the seedlings were grown in the nursery for three months in Plantek-81F containers (volume $85 \mathrm{~cm}^{3}$, BCC Ab). In the autumn of 2017, the seedlings were sampled, and the ${ }^{15} \mathrm{~N}$ content in the plants (roots, needles) and mycorrhiza was analysed by isotope-ratio mass spectrometry coupled to an elemental analyser (Thermo Finnigan). An amount of three mg of ground material was weighed into tin cups and introduced to the EA-IRMS via an autosampler. 
The analytical precision was better than $0.2 \%$ for the $\delta^{15} \mathrm{~N}$, based on replicates of the standards. The nitrogen isotope values were calculated as atom $\%{ }^{15} \mathrm{~N}$ excess (at $\%{ }^{15} \mathrm{~N}$ sample-at $\%{ }^{15} \mathrm{~N}$ natural abundance), and for the treatments with seedlings, given as ${ }^{15} \mathrm{~N}$ content $\left(\mu \mathrm{g}{ }^{15} \mathrm{~N}\right)$ in needles, mycorrhizal root tips and roots by taking into account the mass, nitrogen content, and atom $\%{ }^{15} \mathrm{~N}$ excess values of each plant pool.

\section{EMF colonisation of the seedlings}

The mycorrhizal status of the seedlings was determined by gross microscopy of the outer mantle. The root tips were counted per fine root length, and the colour and texture of the tips (morphotype) were examined under a stereomicroscope (Agerer 1997). The identification of the inoculated EMF morphotypes was confirmed with direct sequencing of the ITS1 region, as described in Velmala et al. (2013).

\section{Statistical analyses}

To determine significant differences between seedling growths on different media, a oneway ANOVA was used, followed by Tukey's test. The difference was reported as significant when $P<0.05$. The assumption of normality was assessed using the Kolmogorov-Smirnov and Shapiro-Wilk tests, and the homogeneity of variances using Levene's test. These statistical analyses were conducted using SPSS software (22.0 version; IBM Corporation, New York, USA).

The relative abundances of EMF morphotypes were subjected to Detrended Correspondence Analysis (DCA) using PC-ORD, version 5.0, using a correlation distance measure. The data matrix consisted of the seedlings' colonisation degrees, as in Table 2.

\section{Results}

\section{Effect of knotwood and stemwood chips on seedling performance}

The growth of seedlings during the first year was negatively affected by the addition of wood chips, especially knotwood chips (Fig. 1). Growth slowdown also depended on the quantity of wood chips (10\% vs 30\%). During the following years (2017 and 2018), the differences levelled off, and the seedlings growing on media with $10 \%$ stemwood (SW) no longer differed from these of the control treatment.

\section{Effect of nutrient-soaked knotwood and stemwood chips on seedling performance and EMF colonisation}

The growth of seedlings was significantly affected by the treatment, both after the first growing season (Table 2) and after the second growing season (Fig. 2). After the first growing season, the lowest seedling growth was observed for unsoaked wood chips (Table 2). Soaking of the SW with nutrients significantly decreased growth reduction (Table 2). All the seedlings amended with nutrient-soaked KW remained smaller than the respective SW ones. Inoculation with EMF had no effect on the growth of the SW amended seedlings, but a trend of increased growth was seen in the inoculated KW treatment. The 


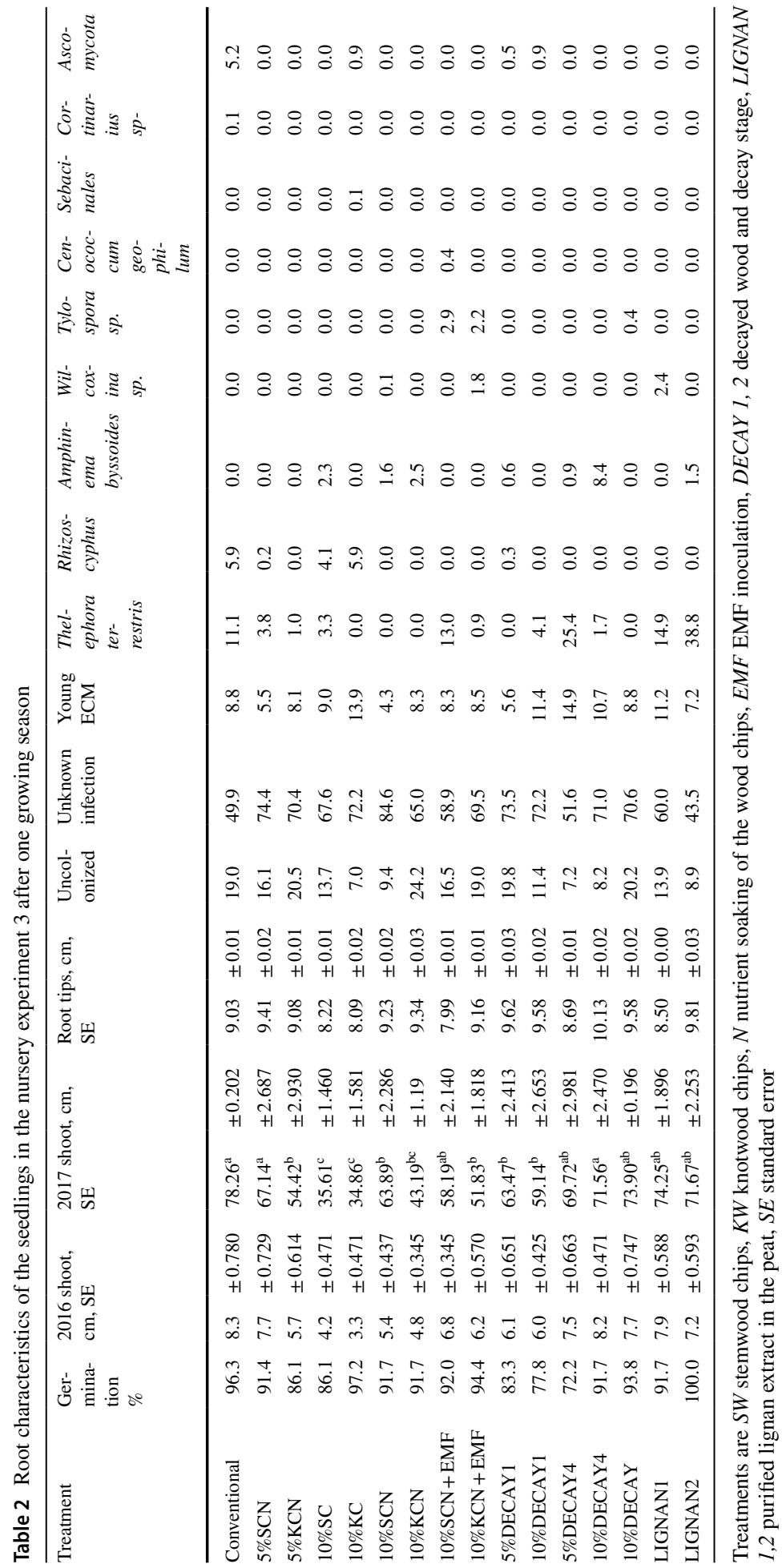


Fig. 1 Nursery experiment 1: Mean shoot heights of the seedlings during the three growing seasons. SW designates stemwood and KW knotwood chips; see other explanations in Table 1. Bars designate SE. Significant differences $(P<0.05)$ between treatments within the same year are indicated by different letters
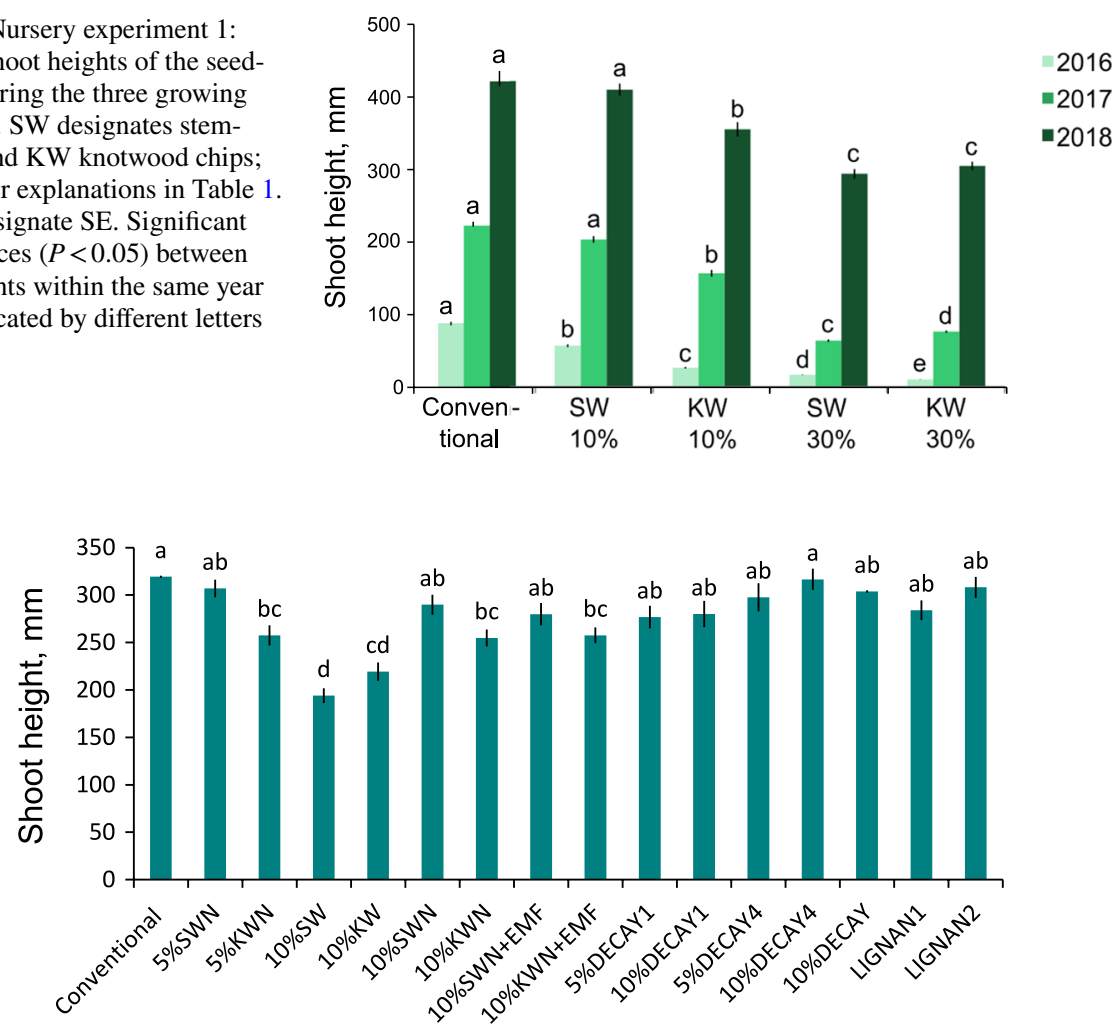

Fig. 2 Nursery experiment 2: Mean shoot heights of the seedlings after two growing seasons. Treatments are SW, stemwood chips; KW, knotwood chips; N, nutrient soaking of the wood chips; EMF, ectomycorrhizal fungi inoculation; DECAY 1, 2 decayed wood and decay stage; LIGNAN 1, 2, purified lignan. \% indicates the proportion of wood chips $(\mathrm{v} / \mathrm{v})$. More detailed information on the treatments in Table 1. Bars designate SE. Significant differences $(P<0.05)$ between treatments are indicated by different letters

decomposed wood of the $1^{\text {st }}$ decay stage decreased seedling growth. However, the addition of more decomposed wood (decay stage 4 or mixture of decay stages 3-5) provided the same growth as the control. The growth of the seedlings in the controls was not negatively affected by the addition of purified lignan extracts. Root tip density was not significantly affected by any of the treatments (Table 2). The seedlings' EMF fungal communities were rather variable and did not respond to the inoculations or any other treatments (Table 2, Supplementary Fig. 1). The germination rate of the seeds showed variable trends, being highest in the Lignan2 treatment and smallest in decay wood treatments (Table 2).

\section{Immobilisation of $\mathbf{N}$ on stemwood and knotwood chips in laboratory incubation experiment}

Wood chips did not immobilise nitrate (data not shown). Ammonium was immobilised dosedependently, with the highest immobilisation observed for the largest quantity of wood chips. Knotwood chips immobilised significantly more ammonium than stemwood chips (Fig. 3a). The immobilisation of ammonium on different wood chips also differed in terms of stability. Knotwood chips provided more stable immobilisation than stemwood chips after both 
Fig. 3 Nitrogen immobilisation experiment: a Immobilisation of ammonium on stemwood (SW) and knotwood (KW) chips; b stability of immobilised $\mathrm{N}$ in the wood chips. Bars designate SE.

Differences between treatments and amounts were always significant $(P<0.05)$
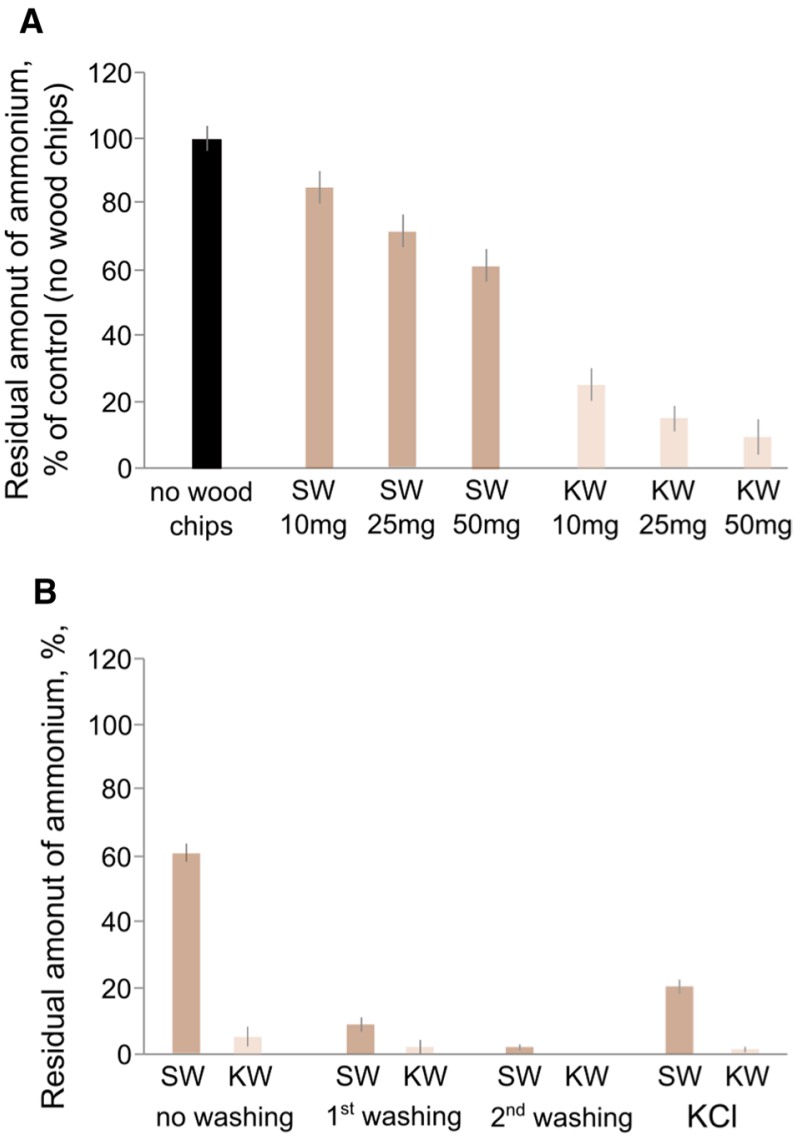

extraction with water and with the common extractant, $1 \mathrm{M} \mathrm{KCl}$ (Fig. 3b). In summary, knotwood chips immobilised with high stability four times more $\mathrm{N}$ than stemwood chips.

\section{Uptake of ${ }^{15} \mathrm{~N}$ immobilised on wood chips by nursery seedlings}

Spruce seedlings growing on conventional nursery substrate amended with wood chips with immobilised nitrogen took up ${ }^{15} \mathrm{~N}$ from both stemwood and knotwood chips (Fig. 4). Labelled ${ }^{15} \mathrm{~N}$ was detected in the needles, roots, and mycorrhizal root tips of the seedlings. However, the seedlings took up significantly more ${ }^{15} \mathrm{~N}$ immobilised on stemwood than on knotwood. Knotwood and stemwood treatments showed different allocation patterns of ${ }^{15} \mathrm{~N}$. In knotwood treatment, we found slightly more ${ }^{15} \mathrm{~N}$ in mycorrhizas than in root or needle pools. In stemwood treatment, the ${ }^{15} \mathrm{~N}$ content in the mycorrhiza was slightly lower than in the roots. 


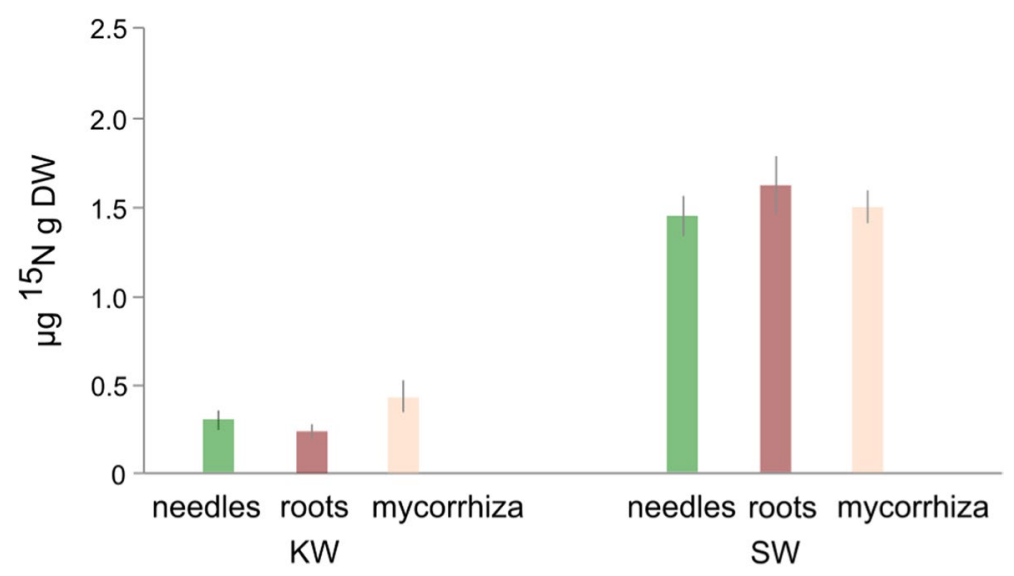

Fig. 4 Uptake of ${ }^{15} \mathrm{~N}$ immobilissed on wood chips (SW- stemwood, KW-knotwood) by the spruce seedlings in the nursery. Difference between SW and KW were always significant. Bars designate SE

\section{Discussion}

We studied the effect of knotwood vs stemwood amendment on the growth of spruce seedlings, their $\mathrm{N}$ uptake, mycorrhization, and reactions between the wood chips and nutrients. Compared to conventionally used peat substrate (control) the addition of wood chips decreased the growth of seedlings dose-dependently. However, this effect levelled off with time. The decrease of growth was especially visible for knotwood chips. We hypothesised that the reason for the decreased growth of seedlings on wood chips was the result of wood chemistry, the quality and quantity of compounds affecting the immobilisation of $\mathrm{N}$ or the toxicity of the substrate, or both. The main composites of wood, i.e. cellulose, hemicellulose, and lignin (Rowell 2005) may not be responsible for changes in growth. However terpenes, phenolics and polyphenolics due to their chemical abilities can play an important role here (Joanisse et al. 2007; Adamczyk et al. 2015, 2017). For example, polyphenolics and terpenes present in both stemwood and knotwood chips may negatively affect enzymatic activities (Adamczyk et al. 2017) and some microbial communities (Kraus et al. 2003; Smolander et al. 2012). Moreover, polyphenolics and terpenes interact with organic N compounds decreasing their availability (Hagerman 2012; Adamczyk et al. 2018, 2019). Stemwood and knotwood chips differ in chemistry, particularly in their terpene and lignan content (Manninen et al. 2002; Piispanen et al. 2008). Lignans are a group of phenols that are characterised by coupling the two phenylpropanoid units by a bond between the positions in the phenyl propane side chains and their concentration in knots even reach up to $30 \%$ (w/w) (Willför et al. 2003, 2004, 2006; Huttula et al. 2018). Thus, these chemical differences in wood components have the potential to explain various seedling growths.

Knotwood chips could decrease seedling growth via a toxic effect. However, there was no decrease of EMF diversity between treatments (Supplementary Fig. 1). In addition, purified lignan fractions seemed not to pose any negative effects for the seedlings' growth or root tip density. Moreover, the effect of pure lignans on seedling germination was positive rather than negative. Thus, like knotwood chips, pure lignan had no toxic effect on seedlings. We therefore estimated the effect of different wood chemistry on plant $\mathrm{N}$ nutrition, as this could have been the main mechanism of growth deceleration. The laboratory 
study confirmed the differences between the immobilisation of ammonium on stemwood vs knotwood chips. The latter not only immobilised four times more $\mathrm{N}$, but also formed more stable complexes with ammonium, suggesting that stronger $\mathrm{N}$ immobilisation may have been the reason for the enhanced reduction of seedling growth. To verify the role of $\mathrm{N}$ immobilisation on seedling growth, we immobilised ${ }^{15} \mathrm{~N}$ on wood chips and added this source of $\mathrm{N}$ to the seedlings. In line with expectations, the uptake of ${ }^{15} \mathrm{~N}$ from knotwood was about four times lower than from stemwood chips, confirming the role of $\mathrm{N}$ immobilisation in seedling growth reduction.

In nursery experiment 2 , we soaked wood chips in nutrients to estimate the extent and persistence of nutrient immobilisation on woody fractions, and how this affected the growth of seedlings. Again, wood chips reduced seedling growth, especially knotwood, but soaking in nutrients levelled this effect off especially when stemwood chips were added. This means that most of the reactive sites of the wood chips able to react with $\mathrm{N}$ were saturated with $\mathrm{N}$ from soaking making it impossible to bind more $\mathrm{N}$ during seedling growth. This was supported by the dead wood amendments. Wood in the $1^{\text {st }}$ stage of decay, chemically the closest to the fresh wood chips, decreased seedling growth similarly to the stem- and knotwood chip amendments. However, wood in the 4th stage of decay did not significantly decrease seedling growth. This may suggest that compounds responsible for decreasing seedling growth are quite decomposed in the early stages of decomposition and/ or underlie leaching with precipitation. Indeed, wood decomposition by fungi is a complex process conducted via a multiple set of fungal species and their enzymes (Rajala et al. 2015). The decomposition of plant cell wall lignocellulose is initiated via a breakdown of covalent bonds and the release of dissolved sugars and lignin-derived aromatic compounds (Lundell et al. 2010).

The wood in the 4th stage of decay may also act as an EMF inoculum, as such wood amendments contain several EMF species (Rajala et al. 2011, 2015). However, this inoculum seemed unviable. The growing substrates were also inoculated with viable EMF mycelia to estimate whether it helped seedlings acquire more nutrients from the wood amendments. Ectomycorrhizal fungi are known for their ability to obtain $\mathrm{N}$ from recalcitrant sources, including $\mathrm{N}$ compounds in complexes with polyphenolics (Wurzburger and Hendrick 2009; Rineau et al. 2012). There were slight indications that EMF-inoculated seedlings were able to rebalance seedling growth more from knotwood treatment than from the respective stemwood. The inoculated strain Tylospora sp. is known to produce $\mathrm{N}$-releasing enzymes (Velmala 2014), but the colonisation degree by Tylopora asterophora remained marginal (2\%), and no great impact of inoculation could therefore be expected. Thus, contrary to the previous study (Vaario et al. 2009) we observed no significant effect of wood chips on the mycorrhization of the seedlings, implying that stemwood and knotwood amendments did not show any toxicity for the EMF communities. Thereby, the nutrient availability of these amendments seemed to be the main factor affecting the seedlings' performance.

\section{Conclusions}

The set of experiments provided by this study suggests that the addition of wood chips to growing media has strong potential to affect seedling growth. However, the effect depends on the spatial location of the wood within logs and thereby on the wood chemistry. The addition of wood chips initially reduced the growth of the seedlings, but the effect levelled 
off with time. We suggest that wood chips affected the growth of seedlings mainly via $\mathrm{N}$ immobilisation, rather than via a direct toxic effect. The immobilisation of $\mathrm{N}$ on wood chips, especially knotwood chips, has potential for developing a slow-release $\mathrm{N}$ source. As such, the use of slow-release $\mathrm{N}$ would be beneficial for plant growth, survival in natural conditions, and environmental protection. All in all, wood chips are an interesting amendment for growing media, but more work is needed to uncover the potential effects of wood amendments on nursery seedlings.

Supplementary Information The online version contains supplementary material available at https://doi. org/10.1007/s11056-021-09887-6.

Funding Open access funding provided by Natural Resources Institute Finland (LUKE).

\section{Declarations}

Conflict of interest We declare no conflict of interest.

Open Access This article is licensed under a Creative Commons Attribution 4.0 International License, which permits use, sharing, adaptation, distribution and reproduction in any medium or format, as long as you give appropriate credit to the original author(s) and the source, provide a link to the Creative Commons licence, and indicate if changes were made. The images or other third party material in this article are included in the article's Creative Commons licence, unless indicated otherwise in a credit line to the material. If material is not included in the article's Creative Commons licence and your intended use is not permitted by statutory regulation or exceeds the permitted use, you will need to obtain permission directly from the copyright holder. To view a copy of this licence, visit http://creativecommons.org/licenses/by/4.0/.

\section{References}

Adamczyk S, Adamczyk B, Kitunen V, Smolander A (2011) Influence of diterpenes (colophony and abietic acid) and a triterpene (beta-sitosterol) on net $\mathrm{N}$ mineralization, net nitrification, soil respiration, and microbial biomass in birch soil. Biol Fertil Soils 47:715-720. https://doi.org/10.1007/ s00374-010-0529-x

Adamczyk S, Kiikkilä O, Kitunen V, Smolander A (2013) Potential response of soil processes to diterpenes, triterpenes and tannins: nitrification, growth of microorganisms and precipitation of proteins. Appl Soil Ecol 67:47-52. https://doi.org/10.1016/j.apsoil.2013.02.009

Adamczyk S, Adamczyk B, Kitunen V, Smolander A (2015) Monoterpenes and higher terpenes may inhibit enzyme activities in boreal forest soil. Soil Biol Biochem 87:59-66

Adamczyk B, Karonen M, Adamczyk S et al (2017) Tannins can slow-down but also speed-up soil enzymatic activity in boreal forest. Soil Biol Biochem 107:60-67

Adamczyk B, Adamczyk S, Smolander A et al (2018) Plant secondary metabolites-missing pieces in the soil organic matter puzzle of boreal forests. Soil Syst 2:2. https://doi.org/10.3390/soils2010002

Adamczyk B, Sietiö O-MM, Straková P et al (2019) Plant roots increase both decomposition and stable organic matter formation in boreal forest soil. Nat Commun 10:3982. https://doi.org/10.1038/ s41467-019-11993-1

Agerer R (1997) Colour atlas of ectomycorrhizae. EinhornVerlag Eduard Dietenberger GmbH, Schnvabisc

Alaspää K, Muukkonen P, Mäkipää R (2016) Lahopuun merkitys kasvualustana eteläboreaalisen vanhan luonnontilaisen kuusimetsän uudistumisessa. Metsätieteen Aikakausk 4:237-245. https://doi.org/10. 14214/ma.6585

Balík J, Híc P, Kulichová J et al (2017) Musts with increased lignan content through addition of lignan extracts. Food Bioprocess Technol 10:1367-1373. https://doi.org/10.1007/s11947-017-1911-6

Boldrin A, Hartling KR, Laugen M, Christensen TH (2010) Environmental inventory modelling of the use of compost and peat in growth media preparation. Resour Conserv Recycl. https://doi.org/10.1016/j. resconrec.2010.04.003 
Burney OT, Jacobs DF (2013) Ungulate herbivory of boreal and temperate forest regeneration in relation to seedling mineral nutrition and secondary metabolites. New for 44:753-768. https://doi.org/10.1007/ s11056-013-9381-9

Flykt E, Timonen S, Pennanen T (2008) Variation of ectomycorrhizal colonisation in Norway spruce seedlings in Finnish forest nurseries. Silva Fenn. https://doi.org/10.14214/sf.234

Grossnickle SC (2000) Ecophysiology of Northern Spruce species. NRC Research Press, Ottawa

Hagerman AE (2012) Fifty years of polyphenol-protein complexes. Recent Adv Polyphenol Res 3:71-97

Harmatha J, Dinan L (2003) Biological activities of lignans and stilbenoids associated with plant-insect chemical interactions. Phytochem Rev 2:321-330. https://doi.org/10.1023/B:PHYT.0000045494. 98645.a3

Huitu O, Kiljunen N, Korpimäki E et al (2009) Density-dependent vole damage in silviculture and associated economic losses at a nationwide scale. For Ecol Manag. https://doi.org/10.1016/j.foreco.2009.06. 013

Huttula M, Patanen M, Piispanen R et al (2018) STXM chemical mapping of Norway spruce knotwood lignans. Microsc Microanal 24:482-483. https://doi.org/10.1017/S1431927618014642

Joanisse GD, Bradley RL, Preston CM, Munson AD (2007) Soil enzyme inhibition by condensed litter tannins may drive ecosystem structure and processes: the case of Kalmia angustifolia. New Phytol 175:535-546. https://doi.org/10.1111/j.1469-8137.2007.02113.x

Johnson O, More D (2004) Collins tree guilde. In: The most complete field guide to the trees of Britain and Europe. HarperCollins Publishers, June 2006

Karst J, Erbilgin N, Pec GJ et al (2015) Ectomycorrhizal fungi mediate indirect effects of a bark beetle outbreak on secondary chemistry and establishment of pine seedlings. New Phytol 208:904-914. https:// doi.org/10.1111/nph.13492

Klavina D, Menkis A, Gaitnieks T et al (2016) Analysis of Norway spruce dieback phenomenon in Latvia: a belowground perspective. Scand J for Res. https://doi.org/10.1080/02827581.2015.1069390

Korkina LG (2007) Phenylpropanoids as naturally occurring antioxidants: from plant defense to human health. Cell Mol Biol 53:15-25

Kraus TEC, Dahlgren RA, Zasoski RJ (2003) Tannins in nutrient dynamics of forest ecosystems: a review. Plant Soil 256:41-66. https://doi.org/10.1023/A:1026206511084

Lundell TK, Mäkelä MR, Hildén K (2010) Lignin-modifying enzymes in filamentous basidiomycetes: ecological, functional and phylogenetic review. J Basic Microbiol 50:5-20

Mäkinen H, Hynynen J, Siitonen J, Sievänen R (2006) Predicting the decomposition of Scots pine, Norway spruce, and birch stems in Finland. Ecol Appl 16:1865-1879. https://doi.org/10.1890/1051-0761(2006) 016[1865:ptdosp]2.0.co;2

Mäkipää R, Leppänen SM, Sanz Munoz S et al (2018) Methanotrophs are core members of the diazotroph community in decaying Norway spruce logs. Soil Biol Biochem 120:230-232. https://doi.org/10. 1016/j.soilbio.2018.02.012

Mandal SM, Chakraborty D, Dey S (2010) Phenolic acids act as signaling molecules in plant-microbe symbioses. Plant Signal Behav 5:359-368. https://doi.org/10.4161/psb.5.4.10871

Manninen AM, Utriainen J, Holopainen T, Kainulainen P (2002) Terpenoids in the wood of Scots pine and Norway spruce seedlings exposed to ozone at different nitrogen availability. Can J for Res. https://doi. org/10.1139/x02-143

McAlister JA, Timmer VR (1998) Nutrient enrichment of white spruce seedlings during nursery culture and initial plantation establishment. Tree Physiol 18:195-202. https://doi.org/10.1093/treephys/18.3.195

Miina J, Saksa T (2013) Perkauksen vaikutus männyn kylvö- ja luontaisen taimikon kehitykseen ja taimikonhoidon ajanmenekkiin. Metsätieteen Aikakausk. https://doi.org/10.14214/ma.6030

Muiruri EW, Barantal S, Iason GR et al (2019) Forest diversity effects on insect herbivores: do leaf traits matter? New Phytol 221:2250-2260. https://doi.org/10.1111/nph.15558

Nisula L (2018) Wood Extractives in conifers: a study of stemwood and knots of industrially important species. Åbo Akademi University Press, Åbo

Piispanen R, Willför S, Saranpää P, Holmbom B (2008) Variation of lignans in Norway spruce (Picea abies [L.] Karst.) knotwood: within-stem variation and the effect of fertilisation at two experimental sites in Finland. Trees 22:317-328. https://doi.org/10.1007/s00468-007-0186-3

Quoreshi AM, Timmer VR (2000) Growth, nutrient dynamics, and ectomycorrhizal development of container-grown Picea mariana seedlings in response to exponential nutrient loading. Can $\mathbf{J}$ for Res. https://doi.org/10.1139/x99-208

Rajala T, Peltoniemi M, Pennanen T, Mäkipää R (2010) Relationship between wood-inhabiting fungi determined by molecular analysis (denaturing gradient gel electrophoresis) and quality of decaying logs. Can J for Res 40:2384-2397. https://doi.org/10.1139/X10-176 
Rajala T, Peltoniemi M, Hantula J et al (2011) RNA reveals a succession of active fungi during the decay of Norway spruce logs. Fungal Ecol 4:437-448. https://doi.org/10.1016/j.funeco.2011.05.005

Rajala T, Peltoniemi M, Pennanen T, Mäkipää R (2012) Fungal community dynamics in relation to substrate quality of decaying Norway spruce (Picea abies [L.] Karst.) logs in boreal forests. FEMS Microbiol Ecol 81:494-505. https://doi.org/10.1111/j.1574-6941.2012.01376.x

Rajala T, Tuomivirta T, Pennanen T, Mäkipää R (2015) Habitat models of wood-inhabiting fungi along a decay gradient of Norway spruce logs. Fungal Ecol. https://doi.org/10.1016/j.funeco.2015.08.007

Read DJ (1996) The structure and function of the ericoid mycorrhizal root. Ann Bot 77:365-374

Rineau F, Roth D, Shah F et al (2012) The ectomycorrhizal fungus Paxillus involutus converts organic matter in plant litter using a trimmed brown-rot mechanism involving Fenton chemistry. Environ Microbiol 14:1477-1487. https://doi.org/10.1111/j.1462-2920.2012.02736.x

Rinne KT, Rajala T, Peltoniemi K et al (2017) Accumulation rates and sources of external nitrogen in decaying wood in a Norway spruce dominated forest. Funct Ecol 31:530-541. https://doi.org/10.1111/ $1365-2435.12734$

Rinne-Garmston KT, Peltoniemi K, Chen J et al (2019) Carbon flux from decomposing wood and its dependency on temperature, wood N 2 fixation rate, moisture and fungal composition in a Norway spruce forest. Glob Chang Biol 25:1852-1867. https://doi.org/10.1111/gcb.14594

Rowell R (2005) Handbook of wood chemistry and wood composites. CRC Press, Boca Raton

Savill P (2013) Pseudotsuga menziesii (Mirb) Franco - Douglas fir. In: Savill P (ed) The silviculture of trees used in British forestry. CABI, Wallingford

Smolander A, Kanerva S, Adamczyk B, Kitunen V (2012) Nitrogen transformations in boreal forest soil: does composition of plant secondary compounds give any explanations? Plant Soil 350:1-16

Vaario L-M, Tervonen A, Haukioja K et al (2009) The effect of nursery substrate and fertilization on the growth and ectomycorrhizal status of containerized and outplanted seedlings of Picea abies. Can $\mathrm{J}$ for Res 39:64-75. https://doi.org/10.1139/X08-156

Velmala S (2014) Sienten kiehtovaa biologiaa yleistajuisesti - ja suomen kielellä. Metsätieteen Aikakausk. https://doi.org/10.14214/ma.6655

Velmala SM, Rajala T, Haapanen M et al (2013) Genetic host-tree effects on the ectomycorrhizal community and root characteristics of Norway spruce. Mycorrhiza 23:21-33. https://doi.org/10.1007/ s00572-012-0446-y

Virjamo V, Julkunen-Tiitto R, Henttonen H et al (2013) Differences in vole preference, secondary chemistry and nutrient levels between naturally regenerated and planted norway spruce seedlings. J Chem Ecol. https://doi.org/10.1007/s10886-013-0352-6

Vuorinen I, Hamberg L, Müller M et al (2015) Development of growth media for solid substrate propagation of ectomycorrhizal fungi for inoculation of Norway spruce (Picea abies) seedlings. Mycorrhiza 25:311-324. https://doi.org/10.1007/s00572-014-0611-6

Wijayanto A, Dumarçay S, Gérardin-Charbonnier C et al (2015) Phenolic and lipophilic extractives in Pinus merkusii Jungh. et de Vries knots and stemwood. Ind Crops Prod 69:466-471. https://doi.org/10. 1016/j.indcrop.2015.02.061

Willför S, Hemming J, Reunanen M et al (2003) Lignans and lipophilic extractives in Norway spruce knots and stemwood. Holzforschung 57:27-36. https://doi.org/10.1515/HF.2003.005

Willför S, Reunanen M, Eklund P et al (2004) Oligolignans in Norway spruce and Scots pine knots and Norway spruce stemwood. Holzforschung 58:345-354. https://doi.org/10.1515/HF.2004.053

Willför SM, Sundberg AC, Rehn PW et al (2005) Distribution of lignans in knots and adjacent stemwood of Picea abies Verteilung von Lignanen in Ästen und im umliegenden Stammholz von Picea abies. Holz Als Roh- Und Werkst. https://doi.org/10.1007/s00107-005-0024-5

Willför S, Smeds A, Holmbom B (2006) Chromatographic analysis of lignans. J Chromatogr A 1112:64-77. https://doi.org/10.1016/j.chroma.2005.11.054

Wurzburger N, Hendrick RL (2009) Plant litter chemistry and mycorrhizal roots promote a nitrogen feedback in a temperate forest. J Ecol 97:528-536

Publisher's Note Springer Nature remains neutral with regard to jurisdictional claims in published maps and institutional affiliations. 